\title{
The long non-coding RNA PCA3: an update of its functions and clinical applications as a biomarker in prostate cancer
}

\author{
Ana Emília Goulart Lemos ${ }^{1,2,}$, Aline da Rocha Matos ${ }^{3, *}$, Luciana Bueno Ferreira ${ }^{4, *}$ \\ and Etel Rodrigues Pereira Gimba ${ }^{2,4,5}$ \\ ${ }^{1}$ Departamento de Epidemiologia e Métodos Quantitativos em Saúde, Escola Nacional de Saúde Pública/Fundação Oswaldo \\ Cruz (FIOCRUZ), Rio de Janeiro, Brazil \\ ${ }^{2}$ Programa de Pós-Graduação em Ciências Biomédicas - Fisiologia e Farmacologia, Universidade Federal Fluminense, Rio de \\ Janeiro, Brazil \\ ${ }^{3}$ Laboratório de Vírus Respiratórios e do Sarampo, Instituto Oswaldo Cruz, Fiocruz, Rio de Janeiro, Brazil \\ ${ }^{4}$ Coordenação de Pesquisa, Instituto Nacional do Câncer, Rio de Janeiro, Brazil \\ ${ }^{5}$ Departamento de Ciências da Natureza (RCN), Instituto de Humanidades e Saúde, Universidade Federal Fluminense, Rio \\ de Janeiro, Brazil \\ *These authors contributed equally to this work
}

Correspondence to: Aline da Rocha Matos, email: aline.matos@ioc.fiocruz.br

Keywords: PCA3; prostate cancer; biomarker; long non-coding RNA (IncRNA); clinical applications

Received: July 18, $2019 \quad$ Accepted: September 24, $2019 \quad$ Published: November 12, 2019

Copyright: Lemos et al. This is an open-access article distributed under the terms of the Creative Commons Attribution License 3.0 (CC BY 3.0), which permits unrestricted use, distribution, and reproduction in any medium, provided the original author and source are credited.

\section{ABSTRACT}

Prostate cancer antigen 3 (PCA3) is an overexpressed prostate long noncoding RNA (IncRNA), transcribed from an intronic region at the long arm of human chromosome 9q21-22. It has been described that PCA3 modulates prostate cancer (PCa) cell survival through modulating androgen receptor (AR) signaling, besides controlling the expression of several androgen responsive and cancer-related genes, including epithelial-mesenchymal transition (EMT) markers and those regulating gene expression and cell signaling. Also, PCA3 urine levels have been successfully used as a PCa diagnostic biomarker. In this review, we have highlighted recent findings regarding $P C A 3$, addressing its gene structure, putative applications as a biomarker, a proposed origin of this IncRNA, roles in PCa biology and expression patterns. We also updated data regarding PCA3 interactions with cancer-related miRNAs and expression in other tissues and diseases beyond the prostate. Altogether, literature data indicate aberrant expression and dysregulated activity of PCA3, suggesting $P C A 3$ as a promising relevant target that should be even further evaluated on its applicability for PCa detection and management.

\section{INTRODUCTION}

Prostate cancer antigen 3 (PCA3) is long non-coding RNA (lncRNA), first described by using differential display experimental approach and named as DD3 [1]. LncRNAs play key roles in a wide repertoire of biological processes by controlling gene expression and their dysregulation has been related to tumor progression [2].

$P C A 3$ is the most specific prostate cancer $(\mathrm{PCa})$ molecule identified to date $[1,3]$. It was identified in 1999, when it was reported as overexpressed in $\mathrm{PCa}$, as compared to non-malignant prostate samples, in addition to presenting a prostate-specific expression pattern [1]. Since its first description, $P C A 3$ roles have been investigated in $\mathrm{PCa}$ and its applicability as a $\mathrm{PCa}$ specific biomarker has also been explored.

This review presents updated information regarding the characterization of this lncRNA since its first description. Consolidation of these data can open new avenues to investigate its role in PCa biology and future effective applications as a biomarker and a therapeutic target. 


\section{PCA3 GENE STRUCTURE}

The first description of $P C A 3$ gene unit reported its location on human chromosome 9q21-22 (Figure 1A) and its $25 \mathrm{~kb}$ length containing four exons (Figure 1B) [1]. According to this report, the primary $P C A 3$ transcript can be submitted to alternative splicing, alternative polyadenylation and produces different sized transcripts. The classical isoform (termed as $P C A 3-5$ ) contains exons $1,3,4 \mathrm{a}$ and $4 \mathrm{~b}$ (Figure 1D). Moreover, the high frequency of stop codons detected in all $P C A 3$ reading frames further evidenced it as a non-coding RNA and no protein or peptide was found to be coded by $P C A 3$ transcripts. The nuclear localization of $P C A 3$ polyadenylated transcripts was demonstrated [3]. However, later reports also showed $P C A 3$ detection into the cytoplasm $[4,5]$.

More recently, a further detailed description of the $P C A 3$ gene structure was performed, presenting a more complex transcriptional unit, including novel additional exons (Figure 1C) [6]. Exon 1 was found to be $1150 \mathrm{bp}$ longer, with 5 possible transcription start sites. Three variants were also described in exon $2(2 \mathrm{a}, 2 \mathrm{~b}$ and $2 \mathrm{c})$ and four additional polyadenylation sites in exon 4 were observed, bringing the total number of polyadenylation sites to 7 [6] (Figure 1C). Besides, four supplementary ORFs were described at upstream regions of the original $P C A 3$ transcript. Furthermore, detailed investigations confirmed that no predicted peptide was coded by any $P C A 3$ transcript [7].

Additional $P C A 3$ isoforms have also been reported, named as $P C A 3$ isoforms 1-4 (Figure 1D), with transcription start sites respectively located at
$1150 \mathrm{bp}, 699 \mathrm{bp}, 640 \mathrm{bp}$ and $136 \mathrm{bp}$ upstream from the original $P C A 3$ start site [6]. PCA3-4 corresponds to only $1 \%$ of total $P C A 3$ transcripts, whereas the PCA3-5 is the major transcript found in PCa tissue samples $[1,7]$ (Figure 1D).

Further investigations on the organization and evolution of the $P C A 3$ gene locus demonstrated that $P C A 3$ is an intronic antisense transcript, mapped in the opposite orientation of the Prune homolog 2 coding (PRUNE2) gene, also called $B M C C 1$ isoform 1 (BMCC1-1), within its intron $6[6]$ (Figure 1C).

\section{PCA3 origin}

An interesting hypothesis regarding $P C A 3$ origin has been proposed. It was suggested that $P C A 3$ originated from an ancient virus sequence that was incorporated into the human genome and therefore could be regulated by virus-specific patterns [8]. According to this report, the presence of additional features in the $P C A 3$ gene could corroborate this hypothesis. First, $P C A 3$ initial gene portion is included in a long interspersed nuclear element type 2 (LINE-2) repeat, a retrotransposon element derived from an ancient virus, which is also the case of the IncRNA $H U L C$, regulated by hepatitis B virus and whose initial portion is also embedded in a long-terminal repeat retrotransposon-like sequence [9]. In addition, it was proposed that the $P C A 3$ promoter does not contain any canonical transcription factor-binding site and lacks any sequence similarity with human promoters. Despite that, a recent report showed that SNAIL transcription factor binds to $P C A 3$ promoter through an E-box element,

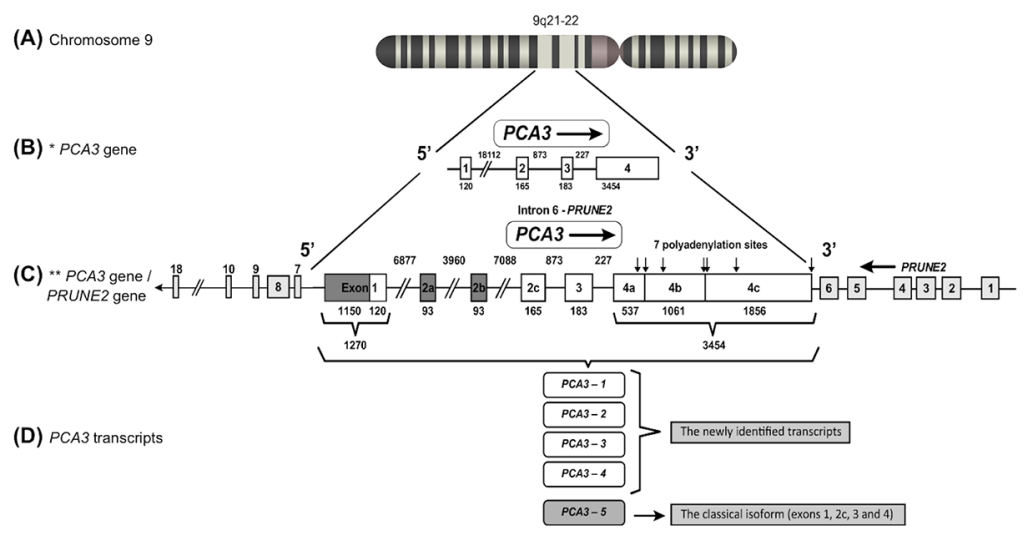

Figure 1: PCA3 gene localization, structure and transcripts. (A) The PCA3 gene is located on human chromosome 9q21-22. (B) The former PCA3 gene structure [1], comprising 4 exons. (C) Updated PCA3 gene structure [6], presenting a more complex transcriptional unit, including additional exons. In this description, exon 1 was found to be 1150 bp longer, comprising 1270 bp. Three alternative spliced exons were described in exon 2 ( $2 a, 2 b$ and $2 c)$ and four additional polyadenylation sites were observed in exon 4, bringing the total number of polyadenylation sites to seven (indicated by vertical arrows). Dark boxes represent the most recently identified PCA3 gene regions, which have 6 exons with alternative splicing of exon $2 \mathrm{a}(93 \mathrm{bp}), 2 \mathrm{~b}(93 \mathrm{bp})$ and 2c (original exon 2 was $165 \mathrm{bp}$ ). PCA3 gene is embedded within the intron 6 of PRUNE2 (also called BMCC1 isoform 1). Light gray boxes represent PRUNE2 exons and white boxes represent PCA3 exons. These two genes are in the opposite orientation. (D) PCA3 transcripts: PCA3 isoforms 1-4 (the more recently identified transcripts by Clarke et al in 2009) and PCA3-5 (the classical isoform). 
activating $P C A 3$ expression [10]. Furthermore, $P C A 3$ localization in the opposite strand of PRUNE2 (Figure $1 C)$ is also similar to the case of Epstein-Barr virus bidirectional transcription, with the opposite direction mainly associated with the transcription of noncoding and regulatory genes [11]. Moreover, $P C A 3$ adenosine deaminases acting on RNA (ADAR) mediated editing is also a post-transcriptional mechanism largely employed in the cellular responses to viruses [11]. Despite these intriguing speculative evidence, experimental data are still needed to validate this hypothesis.

\section{PCA3 FUNCTIONAL ROLES IN PROSTATE BIOLOGY}

The description of $P C A 3$ roles in $\mathrm{PCa}$ tumor biology was pioneered and reported by our group [12]. Our investigation reported that transient knockdown of $P C A 3$ transcripts reduced cell growth and viability, in addition to inducing apoptotic cell death. These data reinforced the hypothesis that $P C A 3$ could modulate $\mathrm{PCa}$ cell survival. We also reported an association between $P C A 3$ and the androgen-receptor (AR) signaling pathway (Figure 2). We found that cells treated with AR agonist dihydrotestosterone (DHT) induced significant upregulation of $P C A 3$ expression, which was reversed by AR antagonist flutamide. In addition, we also observed upregulation of androgen-responsive genes (ARGs) (TMPRSS2, NDRG1, GREB1, PSA, AR, FGF8, CdK1, $C d K 2$, and PMEPA1) in response to DHT treatment. Interestingly, these findings were reversed when silencing $P C A 3$ using RNA interference [12].

Some additional data have also indicated that $P C A 3$ and PRUNE2 may have similar responsive mechanisms and evolutionary patterns [6]. However, regarding PRUNE2 expression levels in response to androgen induction, these data are controversial, as follows. Clarke et al. showed that PRUNE2 levels were induced by AR stimulation [6], whereas Salameh et al. observed that androgen stimulation decreased PRUNE2 levels, besides inducing a concomitant increase in $P C A 3$ expression. Thus, PRUNE2 PCA3 regulation appears to be sensitive to AR activation, one of PCa molecular hallmarks [13].

Salameh et al. showed a functional relationship between $P C A 3$ and PRUNE2, by demonstrating that $P C A 3$ modulated PRUNE2 expression [13] (Figure 2). These authors proposed that this modulation could be mediated

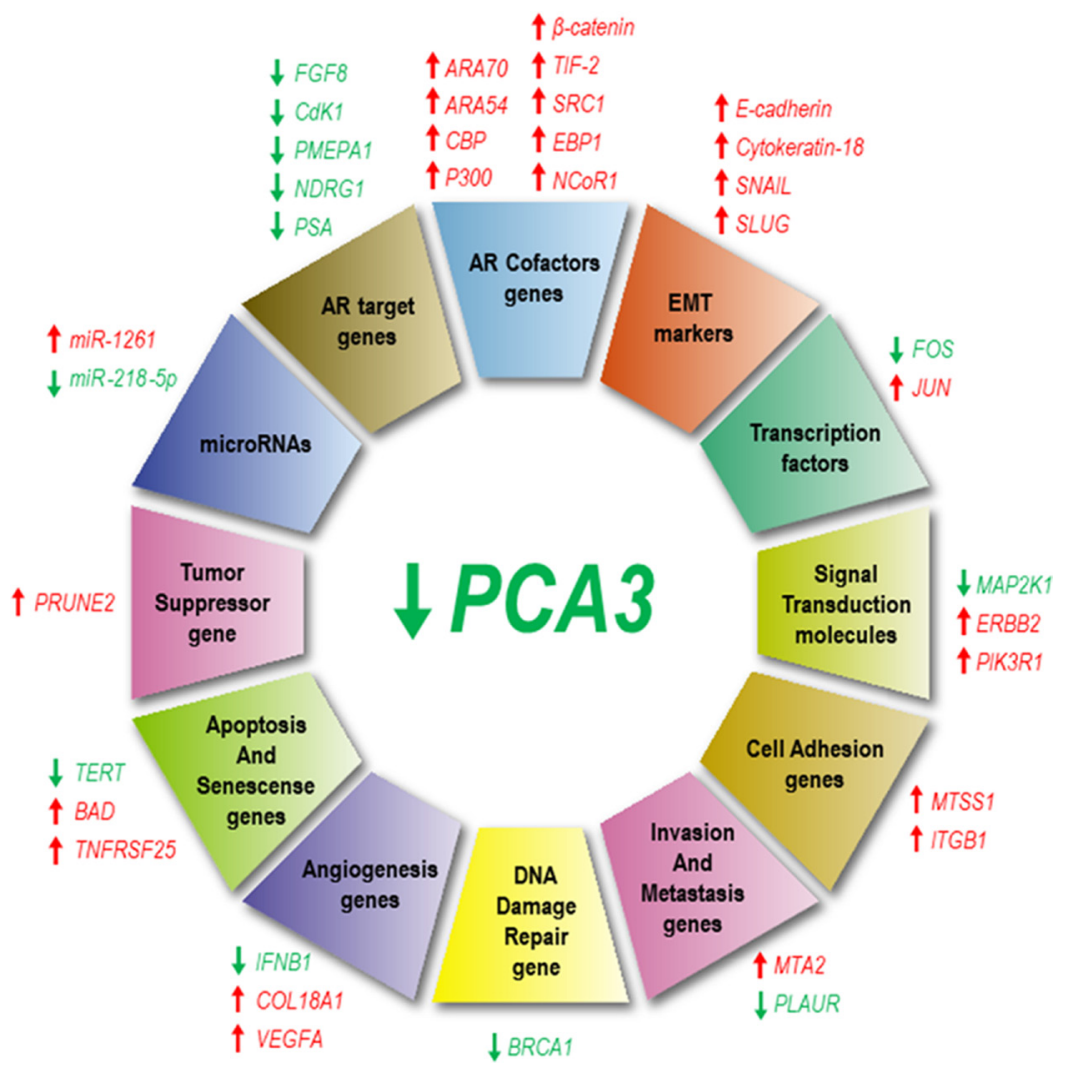

Figure 2: PCA3 silencing modulates the expression of several genes and microRNAs. Genes that have been downregulated in response to PCA3 silencing are represented by green arrows, while those upregulated are indicated by red arrows. Overview of different genes which expressions are modulated by PCA3, classified according to their functional roles: androgen receptor (AR) targets and cofactors, epithelial-mesenchymal transition (EMT), transcription, signaling transduction, cell adhesion, invasion and metastasis, DNA damage repair, angiogenesis, apoptosis and senescence, tumor suppression and miRNAs. 
by ADARs. In this proposed mechanism, $P C A 3$ bound to PRUNE2 pre-mRNA forms a double-stranded RNA with $P R U N E 2$, which is then ligated to ADAR proteins, that in turn regulate PCA3 and PRUNE2 levels [13]. These enzymes are required for a co-regulatory effect on both RNAs, where $P C A 3$ negatively regulates $P R U N E 2$ levels and vice-versa (Figure 2).

It has been demonstrated that $P C A 3$ and $P R U N E 2$ display opposite roles in both in vitro and in vivo models of PCa [13]. These authors described that $P C A 3$ silencing or PRUNE2 ectopic overexpression decreased cell proliferation and transformation in vitro. In addition, PCa cells overexpressing PRUNE2 presented decreased cell adhesion, spreading and migration, while $\mathrm{PCa}$ cells in which PRUNE2 was stably silenced presented larger tumor xenografts. These data showed the tumor suppressor activity of PRUNE2. In conclusion, silencing ADARI in LNCaP PCa cell line, which increased PRUNE2 expression as opposed to decreased $P C A 3$ levels, reduced tumor cell proliferation in vitro and in vivo, further demonstrating a functional role for the PRUNE2/PCA3 regulatory axis in $\mathrm{PCa}$ [13].

A later report by our group [14] presented further comprehensive mechanisms for $\mathrm{LNCaP}$ cell line survival rates modulated by $P C A 3$. We found that $\mathrm{LNCaP}$ cells in which $P C A 3$ was knocked-down induced the expression from 16 out of 84 tested tumor markers, including those involved in transcription control, cell signaling, angiogenesis, apoptosis, cell senescence, invasion, metastasis, cell adhesion and DNA damage repair [14] (Figure 2). These data indicated that $P C A 3$ modulated PCa cell survival through regulating the expression of key cancer-related genes (Figure 2), mainly those involved in controlling gene expression and cell signaling. $P C A 3$ knockdown also induced a significant upregulation of the cofactors ARA70, ARA54, CBP, P300, $\beta$-catenin, TIF-2, SRC1, EBP1, and NCoR1. These data further proposed that the upregulation of AR cofactor transcripts could be one of the possible mechanisms by which ARGs are negatively modulated in response to $P C A 3$ silencing [14]. Furthermore, $P C A 3$ modulated the expression of some EMT markers (E-cadherin, cytokeratin-18, SNAIL and TWIST), with some evidence that $P C A 3$ downregulation does not induce a complete reversion in the expression of epithelial and mesenchymal markers, which was compatible with a partial EMT (Figure 2). Moreover, by stable silencing $P C A 3$ transcript, PCa cell viability was lost [14], as observed when using $P C A 3$ transient silencing [12]. These data supported the proposal of $P C A 3$ knockdown as a putative therapeutic approach to inhibit $\mathrm{PCa}$ growth [14]. Further evidencing the key role of $P C A 3$ on PCa cell survival, it was reported that $P C A 3$ silencing sensitized $\mathrm{PCa}$ cells to enzalutamide-induced loss of cell growth, reinforcing the link between $P C A 3$ and modulation of AR signaling [15].

\section{PCA3 and microRNAs}

The interaction between lncRNAs, including $P C A 3$, and microRNAs (miRNAs) can influence post-transcriptional regulation, as lncRNAs can act as competing endogenous RNAs [16]. LncRNAs have miRNA responsive elements, to which miRNA binds and sponges, controlling miRNAs endogenous availability to bind to their own mRNAs targets, thus affecting their expression [17]. In a recent report, a search for miRNAs presenting base pairing with $P C A 3$ was performed and 14 miRNAs were identified. Among further validated miRNAs, miR-1261 was differentially expressed in response to $P C A 3$ knockdown. In addition, the overexpression of miR-1261 induced PCA3 downregulation, evidencing a regulatory effect between $P C A 3$ and $m i R-1261$ [10] (Figure 2).

It was also suggested that $P C A 3$ could target $m i R$ 218-5p [18], a miRNA that negatively regulates PCa cell invasion, proliferation [19], migration [20] and tumor angiogenesis [21]. PCA3 knockdown decreased miR-218$5 p$ expression levels in vitro and in vivo (Figure 2) and $m i R$ 218-5 $p$ suppressive effects over PCa biological functions are related to high mobility group box 1 (HMGB1) protein repression, suggesting that the PCA3-miR-218-5p-HMGB1 axis could be important for PCa progression [18]. Of note, the $m i R-218-5 p$ is also targeted and regulated by other lncRNAs, such as MALAT1 and CCAT1 [22, 23].

\section{PCA3 AS A BIOMARKER}

Since its first description, $P C A 3$ has been especially investigated due to its major overexpression in PCa cells. This paramount attribute has highlighted the importance of further evaluation of its potential clinical usefulness. Therefore, PCA3 molecular tests have been proposed, based on its detection by quantitative real-time PCR (qPCR), aiming to detect PCa cells in body fluids and urinary sediments, after digital rectal examination (DRE) [24, 25]. Since 2012, PCA3 was approved as an auxiliary biomarker in the molecular diagnosis of $\mathrm{PCa}$ in the European Union, Canada and the United States [26]. Table 1 summarizes the reports on this issue.

\section{PCA3 as a diagnostic biomarker}

Considering current prostate-specific antigen (PSA) limitations as a biomarker for PCa [27], new PCa biomarkers have been proposed to improve the accuracy of PSA in the management of early PCa, including PCA3. Different from PSA, PCA3 expression levels seem to be independent of patient age, inflammation, trauma or 
Table 1: Main findings of PCA3 as a marker for diagnosis, prognosis and active surveillance (AS)

\begin{tabular}{cl}
\hline Study & \multicolumn{1}{c}{ Assessment } \\
\hline$[28]$ & $\begin{array}{l}\text { Diagnosis } \\
\text { metabolites); PCA3 }\end{array}$ \\
{$[29]$} & $\begin{array}{l}\text { Blood and urine specimens (mRNA); PCA3 and } \\
\text { TMPRSS2:ERG }\end{array}$ \\
{$[30]$} & Urine specimens (mRNA); PCA3 \\
{$[31]$} & Biopsy specimens (mRNA); PCA3 \\
& \\
{$[33]$} & Urine specimens (mRNA); PCA3 \\
&
\end{tabular}

[47] Urine specimens (mRNA); PCA3

[51] Urine specimens (mRNA); $P C A 3$

[54] CTC in blood (mRNA)

PCA3

[61] Urine specimens (mRNA); PCA3 and TMPRSS2:ERG

[62] Peripheral blood (mRNA); PCA3, $P S A$ and $h K 2$

[63] Urine specimens (mRNA) PCA3 and PSA

[64] Urine specimens (mRNA); PCA3, PSMA and PSGR

\section{Prognosis and Active Surveillance (AS)}

[68] Blood and urine specimens (mRNA) PCA3, PHI and sarcosine

[74] Urine specimens (mRNA); $P C A 3$

[75] Urine specimens (mRNA); PCA3

[76] Urine specimens (mRNA); PCA3

Non-invasive urine-based testing represented a rich source of novel biomarkers for $\mathrm{PCa}$

Serum and urine molecular biomarkers have been identified including $P C A 3$, which was introduced clinically

The APTIMA PCA3 assay added specificity to the algorithm for $\mathrm{PCa}$

$P C A 3$ as a first-line screening test showed improved performance

$P C A 3$ score was highly correlated with the risk of having cancer on re-biopsy, and could prevent unnecessary prostate biopsies

The quantitative RT-PCR assay for $D D 3^{P C A 3}$, bringing great promise for molecular urine analysis, reducing the number of unnecessary biopsies

Chronic prostatitis did not influence the $P C A 3$ score

$P C A 3$ density showed a significant increase in specificity when compared with PSA, PSAD and $P C A 3$

A chip-based device platform using PCA3 mRNA as a target to capture CTC was developed

Urinary testing for TMPRSS2:ERG and PCA3 could avert unnecessary biopsy

Combining PCA3, PSA, and $h K 2$ showed better performance than individual biomarkers alone in predicting $\mathrm{PCa}$

The combination of $P C A 3$ with $P S A$ gives better overall performance in identification of $\mathrm{PCa}$ than serum $P S A$ alone in the high-risk population

PSMA, PSGR, and PCA3 scores were significant predictors of $\mathrm{PCa}$ using a multiplex model

$P C A 3, \mathrm{PHI}$ and sarcosine have been identified as predictors of $\mathrm{PCa}$ characteristics at final pathology

$P C A 3$ provided incremental prognostic information in the AS setting

The urinary PCA3 test predicted Gleason grade re-classification amongst patients receiving a 5ARI during AS for low-risk PCa

The prognostic significance of $P C A 3$ was confirmed as associated with tumor volume and Gleason score 


\begin{tabular}{|c|c|c|}
\hline Study & Assessment & Main findings \\
\hline$[81]$ & $\begin{array}{l}\text { Urine specimens (mRNA); PCA3 and TMPRSS2- } \\
E R G\end{array}$ & $\begin{array}{l}\text { Urinary } P C A 3 \text { and } T M P R S S 2-E R G \text { scores did not } \\
\text { appear to be useful in assessing response to ADT } \\
\text { in advanced } \mathrm{PCa}\end{array}$ \\
\hline$[82]$ & Urine specimens (mRNA); PCA3 & Dutasteride effect on the $P C A 3$ score was variable \\
\hline$[83]$ & Peripheral blood specimens (DNA); $P C A 3$ & $\begin{array}{l}\text { The presence of the (TAAA)n STR polymorphism } \\
\text { in the } P C A 3 \text { promoter region may be a risk factor } \\
\text { for } \mathrm{PCa} \text { in the Chinese population }\end{array}$ \\
\hline$[85]$ & Peripheral blood mononuclear cells (DNA); $P C A 3$ & $\begin{array}{l}\text { The occurrence of a STR polymorphism might be } \\
\text { related to the mutations of } P C A 3 \text { upstream loci }\end{array}$ \\
\hline$[86]$ & $\begin{array}{l}\text { FFPE tissue blocks } \\
\text { (DNA); } P C A 3\end{array}$ & $\begin{array}{l}\text { A TG dinucleotide repeat in } P C A 3 \text { was } \\
\text { significantly associated with PCa risk and } \\
\text { aggressiveness }\end{array}$ \\
\hline [89] & Blood samples (DNA); PCA3 & $\begin{array}{l}\text { Carriers of the polymorphism } P C A 3-845 \mathrm{G}>\mathrm{A} \\
\text { had a higher risk for metastatic PCa }\end{array}$ \\
\hline
\end{tabular}

Abbreviations: 5-ARI: 5-Alpha Reductase Inhibitors; ADT: androgen deprivation therapy; AS: active surveillance; CTC: circulating tumor cells; FFPE: formalin-fixed paraffin embedded; hK2: human kallikrein 2; mRNA: messenger RNA; PCa: prostate cancer; PCA3: prostate cancer antigen 3; PHI: prostate health index; PSA: prostate specific antigen; PSAD: prostate specific antigen density; PSGR: prostate specific G protein coupled receptor; PSMA: prostate-specific membrane antigen; RT-PCR: reverse transcription polymerase chain reaction; STR: short tandem repeat.

prior biopsies [28] and can be detected and quantified in urine [29]. The urinary $P C A 3$ as a test to detect $\mathrm{PCa}$ was approved by the US Food and Drug Administration (FDA) and is available to be used in private hospitals and clinics for PCa diagnosis [30]. It is a urine test, followed by a rectal examination, to facilitate the PCA3 to go into the urine. However, its utility as a first line test or to detect high-grade $\mathrm{PCa}$ disease remains controversial since some authors found a low sensitivity of using $P C A 3$ as biopsy indicator. It has been discussed that the $P C A 3$ score would fail to detect $36 \%$ of advanced cases in men with low PSA values [31].

The combination of DRE and PSA allows a correct PCa risk stratification in the majority of cases, although a significant proportion of indeterminate results lead uncertain physicians to perform a prostate biopsy [32]. Thus, $P C A 3$ test has been useful in clinical trials to guide the decision of those patients that will perform biopsy or re-biopsy after an initial negative biopsy with continued suspicion of $\mathrm{PCa}[33]$. In this context, the Progensa PCA3 test is a commercial available kit approved by the US FDA for men $\geq 50$ years old with a previous negative biopsy and a persistent elevated PSA level to aid in decisionmaking regarding repeated biopsies [34].

$P C A 3$ transcript levels are measured through $\mathrm{qPCR}$ by Progensa test in urine samples obtained after a prostate massage in order to achieve the maximum number of prostatic cells. This measurement must be performed together with the PSA transcript, which has similar expression levels in tumor and benign cells. Thus, a $P C A 3$ score based on the ratio of $P C A 3$ to PSA transcripts can be determined [35].

The thresholds used for the $P C A 3$ score are still controversial. Several groups used a $P C A 3$ score threshold $\geq 35$ [34, 36-41], while others explored values $\leq 35$ [37, 40, 42-45] (Table 2). For instance, recent studies have demonstrated that a PCA3 score of 35 provides an optimal balance between sensitivity and specificity in diagnosing $\mathrm{PCa}$ with greater diagnostic accuracy than free/total PSA (cut-off 25\%) [36, 38]; on the other hand, a PCA3 score threshold lower than 25 could be predictive of pathological indolent $\mathrm{PCa}$ [42].

PCA3 score has been quite discussed, especially regarding the application to clinical practice. It seems practical to establish thresholds for guiding repeated biopsy decisions. Both the USA and European repeated biopsy studies have indicated that a $P C A 3$ score threshold of 35 could provide an optimal balance between sensitivity and specificity for detecting PCa [38]. Many studies have also reported that the $P C A 3$ score has been correlated to $\mathrm{PCa}$ significance. Some authors have found that the mean $P C A 3$ score was lower in men with indolent PCa than in those with clinically significant $\mathrm{PCa}$, both in men with a positive biopsy and in those undergoing radical prostatectomy (RP) [37]. Other studies also found that $P C A 3$ score was higher in biopsies presenting $\mathrm{GS} \geq 7$, than in those samples with GS $<7[36,44]$. Furthermore, higher PCA3 score was significantly correlated with larger tumor volume [44], while the median score was correlated with tumors presenting extracapsular extension [39]. Although these data demonstrate that $P C A 3$ score is related to PCa significance, 
Table 2: Outcomes for different PCA3 thresholds

\begin{tabular}{ccl}
\hline Study & Threshold & \multicolumn{1}{c}{ Threshold relevance } \\
\hline$[37]$ & 50 & $\begin{array}{l}\text { Identification of men at high risk of harboring significant PCa who are candidates } \\
\text { for RP }\end{array}$ \\
{$[39]$} & 47 & Providing a correlation between PCA3 score and tumor volume \\
{$[34,38]$} & 35 & Optimal balance between sensitivity of $58 \%$ and specificity of $72 \%$ \\
{$[36]$} & 35 & Increased risk of PCa \\
{$[41]$} & 35 & Optimal balance with sensitivity of 54\% and specificity of $74 \%$ \\
{$[40]$} & 24 and 35 & $\begin{array}{l}\text { Independent predictors in multivariable intermediate-and high-grade disease } \\
\text { models }\end{array}$ \\
{$[42]$} & 25 & Predictive of pathological indolent PCa \\
{$[43]$} & 25 & Optimal balance between sensitivity and specificity, and also NPV is greater \\
{$[44]$} & 25 & enhanced \\
{$[37]$} & 20 & Effective to determine which men are candidates for AS \\
{$[45]$} & 17 & Selecting men with clinically insignificant PCa in whom AS may be appropriate \\
\hline
\end{tabular}

Abbreviations: RP: radical prostatectomy; PCa: prostate cancer; NPV: negative predictive value; AS: active surveillance: PA: predictive accuracy.

there are three studies that were not able to show this relationship [46-48]. The association between $P C A 3$ levels and $\mathrm{PCa}$ significance should be further investigated.

$P C A 3$ has been shown to be PCa specific, since its expression is not influenced by other clinical conditions, such as chronic prostatitis, on the contrary of PSA levels. In such a situation, urinary $P C A 3$ test has been majorly recommended as a valuable tool to better identify those patients who really need to perform prostate biopsies. PCA3 score was found to be negative (less than the usual threshold of 35 ) in a series of 38 patients, suggesting that $P C A 3$ test can be used as a valuable tool in patients with raised PSA levels and suspicion of chronic prostatitis, in order to distinguish those patients who will really benefit from prostate biopsy [49]. Such data are in agreement with other reports, in which it was demonstrated that $P C A 3$ score was similar in patients with benign prostatic hyperplasia (BPH) and/or normal parenchyma at biopsy in a large series with chronic prostatitis and high-grade prostatic intraepithelial neoplasia (HG-PIN) [50].

Several efforts have been made in order to improve the detection of PCa prior to biopsy by using additional approaches based on $P C A 3$ evaluation, such as the application of $P C A 3$ density evaluation [PCA3D: the ratio of urinary $P C A 3$ score/prostate volume (PV)]. Many authors have clearly established a correlation between tumor volume, as assessed from RP specimens, and PCA3 score $[40,44,51]$. Some authors postulated that reporting $P C A 3$ score in relation to total PV could be of diagnostic interest, since the ratio $P C A 3 \mathrm{D}$, would represent the proportion of PV occupied by the tumor [52]. In this study, they found higher diagnostic accuracy for $P C A 3$ score and $P C A 3 \mathrm{D}$ than PSA and PSAD (ratio of urinary PSA score/PV). Corroborating these data, others also showed a significant increase in $\mathrm{PCa}$ diagnostic specificity using $P C A 3 \mathrm{D}$ when compared to PSA, PSAD and PCA3 score. These authors concluded that $P C A 3 \mathrm{D}$ could be used as a mini-nomogram with a $70 \%$ risk of positive initial biopsy when $P C A 3$ score $>$ PV [53].

A prospective study including 594 samples addressed for initial prostate biopsy and PCA3-based nomograms tests provided significant predictive accuracy for $P C A 3$ score. The urinary $P C A 3$ test and the $P C A 3-$ incorporating nomograms can be considered as additional reliable tools to support the initial biopsy decision [54].

However, certain limitations regarding the use of PCA3 molecule should be considered. As a typical RNA molecule, which have sequences that contain the active RNA degradation systems and therefore present defects in processing, folding, or assembly with proteins, being rapidly degraded by the surveillance machinery, PCA3 is unstable and its capture and preservation needs to be accurate. Aiming to circumvent this limitation, some approaches have been tested in order to improve higher yields of RNA extraction, such as commercially available magnetic beads (Mag-Cap), phenol-chloroform, affinity columns or Mag-Cap for RNA extraction in urine samples [55].

Another issue of widespread interest for clinicians is the capture of circulating tumor cells (CTC) from the blood. In this context, Sioss et al. [56] developed a platform using RNA purified by enriched CTCs from blood samples, using $P C A 3$ as target. The platform consists of a chip-based device, which utilizes antisense 
oligonucleotides attached to silica-coated nanowires (NWs) to detect $P C A 3$.

More recent, combinations between $P C A 3$ and other biomarkers are emerging, including TMPRSS2:ERG fusion [57-61]. TMPRSS2 (androgen-regulated transmembrane protease serine 2), is fused to the ETS-related gene $(E R G)$. A truncated ERG protein is overexpressed following androgenic stimulation of the TMPRSS2 promoter [62]. The combination of these two biomarkers in the urine after DRE improved the specificity for detecting PCa with GS $\geq 7$. The authors stressed that $42 \%$ of unnecessary prostate biopsies would have been avoided by using the urine assay results in order to select men to perform biopsy [63].

In an attempt to improve $\mathrm{PCa}$ diagnosis, some studies have demonstrated better results of $P C A 3$ in association with PSA $[64,65]$, in addition to prostatespecific G-protein coupled receptor (PSGR) [66], a biomarker previously described to be overexpressed in PCa tissue [67]. Other authors found that the combination of PCA3, PSA, and human kallikrein 2 (hK2) largely improved area under the curve (AUC)-receiver operating characteristic (ROC), especially those patients presenting PSA 4-10 ng/mL [64]. PCa was quantitatively detected through overexpressed $P C A 3$ and PSA genes, in urine sediments of men with $\mathrm{PCa}$ or $\mathrm{BPH}$, after prostatic massage. The aforementioned markers combined had a sensitivity of $80.2 \%$ and a specificity of $100 \%$ [68].

Recent data also revealed that a logistic regression algorithm combining $P C A 3$ with PSA significantly increased PCa diagnostic properties [65]. This combined evaluation was able to discriminate low-grade from highgrade cancers. These data suggest that $P C A 3$ improves the diagnostic sensitivity and specificity of PSA and that the combination of $P C A 3$ with PSA analysis provides better overall performance in identification of $\mathrm{PCa}$ than serum PSA evaluation alone in the high-risk population.

A multiplexed qPCR assay, using the combination of the three overexpressed genes in $\mathrm{PCa}$, which are prostatespecific membrane antigen (PSMA), PSGR and PCA3 on urine sediments from patients who were indicated for prostate biopsy, provided an improve on the predictive ability when compared to the same test using PCA3 or PSA genes alone [66]. These results further indicated the clinical usefulness of the PCA3 and PSA combination as better approaches in the early diagnosis of $\mathrm{PCa}$.

\section{PCA3 in prognosis and active surveillance (AS)}

PCA3 evaluation has also been proposed for monitoring and predicting $\mathrm{PCa}$ clinical outcome, which would likewise aid in treatment decision strategies. An increasing body of evidence will be discussed herein showing that $P C A 3$ levels have been associated with PCa aggressiveness. Despite that, there are also contradictory reports that fail to report the correlation of $P C A 3$ levels and $\mathrm{PCa}$ outcomes. Additionally, one of the proposed clinical utilities of $P C A 3$ is its use in approaches that could screen those patients that could benefit from active surveillance (AS), a conservative management option for men with low-risk PCa that ought to decrease overtreatment. The majority of AS protocols require serial prostate biopsies, associated with patient discomfort and risk of complications [69].

It was reported that $P C A 3$ levels, as well as Prostate Health Index (PHI) and sarcosine levels, were positively associated with some prognostic markers, as tumor volume $\geq 0.5 \mathrm{~mL}$, pathologic GS $\geq 7$ and pT3 disease [70]. In addition, other authors showed that adding PHI and $P C A 3$ to the AS inclusion criteria of the contemporary Epstein and the Prostate Cancer Research International: Active Surveillance (PRIAS) protocols improved their prognostic performance to predict the presence of pathologically insignificant prostate cancer, in a retrospective study with patients who underwent RP but would be eligible for AS [71].

The prognostic validity of $P C A 3$ and TMPRSS2:ERG fusion transcripts, in combination, have been investigated, which showed their potential to reduce unnecessary prostate biopsies and guide risk stratification, besides being more specific than serum PSA [72]. It was also reported that PCA3, TMPRSS2:ERG and PHI were predictors of a tumor volume $\geq 0.5 \mathrm{~mL}$, although multifocality was only predicted by $P C A 3$ score, in patients who underwent RP for biopsy-proven $\mathrm{PCa}$ [73].

Moreover, high $P C A 3$ scores in urine have been significantly correlated with a high GS, percentage of positive biopsy cores and advanced clinical stage [74]. An additional report also showed that the $P C A 3$ score values were associated with greater tumor aggressiveness, as measured by correlation with GS [75]. In another investigated AS cohort, it was shown that men with GS reclassification (GR) had higher first $P C A 3$ (fPCA3) and subsequent $P C A 3$ (sPCA3) levels [76]. Additionally, a prospective phase II study described that the $P C A 3$ test predicted the risk of GR in patients at low-risk PCa patients, in AS, complemented with 5-alpha-reductase inhibitor prescription [77]. Further, a recent report confirmed the prognostic value of the $P C A 3$ score, which was positively associated with PCa tumor volume and GS [78].

Conversely, it is important to mention that some analysis were unsuccessful in showing $P C A 3$ validity for prognostic use. Some authors demonstrated that $P C A 3$ presented low sensitivity and high false negative rates for predicting high GS in initial biopsy (GS $\geq 8$ ). Additionally, in patients submitted to RP, low $P C A 3$ levels were associated with adverse pathological features in RP, clinical recurrence outcome and the greater probability of metastatic progression [79]. Moreover, in a cohort of patients in AS, PCA3 was not an independent predictor of PCa diagnosis on repeat biopsies [80]. Another report also found no correlation between $P C A 3$ score and GS on 
biopsy or clinical tumor stage, although it was presented as a valuable diagnostic biomarker for $\mathrm{PCa}$ [81]. Other authors showed no correlation between $P C A 3$ score and GS or pathological stage of prostatectomy samples, even though it was associated with total tumor volume, apical and basal invasion, bilaterality and multifocality [82].

Hence, the potential use of $P C A 3$ as a prognostic biomarker is still under investigation and discussion. Clinical evidence is yet at early stages to consider this transcript as a biomarker candidate for $\mathrm{PCa}$ prognosis and further efforts are needed to elucidate this question. Also, some investigations demonstrated that PCA3 levels in the urine may be significantly affected by androgen deprivation therapy, which would restrict the consideration of PCA3 levels to monitor PCa clinical course [83, 84].

\section{PCA3 DETECTION IN EXOSOMES - POTENTIAL USE}

The exosomes are extracellular vesicles secreted from prostate non-tumoral and malignant cells present in a variety of body fluids (blood, urine, semen and prostatic fluid). Prostate and cancer-associated markers are also present in urinary exosomes [85]. Because multiple exosomes have been associated with both PCa and elevated GS, there is increasing interest in investigating the exosomes as a potential source of biomarkers for PCa [86]. In this scenario, $P C A 3$ has been detected in urinary exosomes, in which their content is protected from degradation [87]: (Figure 3). The levels of PCA3 and ERG prostate-biomarkers have been compared in urine samples and it was found that the whole urine could be the substrate for PCa diagnosis. It has also been found that among various cancer-related genes, $P C A 3$ could differentiate biopsy positive patients from those negative using RNA isolated from exosomes [88]. Although the results are promising, larger studies are needed to confirm the potential clinical usefulness of $P C A 3$ detection in exosomes, which must be prospectively assessed in larger clinical cohorts.

\section{PCA3 EXPRESSION IN NON-PROSTATIC TISSUES}

PCA3 transcript expression has been mainly associated with prostate tissues, and it had been proposed for quite some time that it was a prostate-specific gene product $[1,89]$. However, the expression of this IncRNA has been recently described in other tissues and pathological conditions. The detection of $P C A 3$ in ovarian

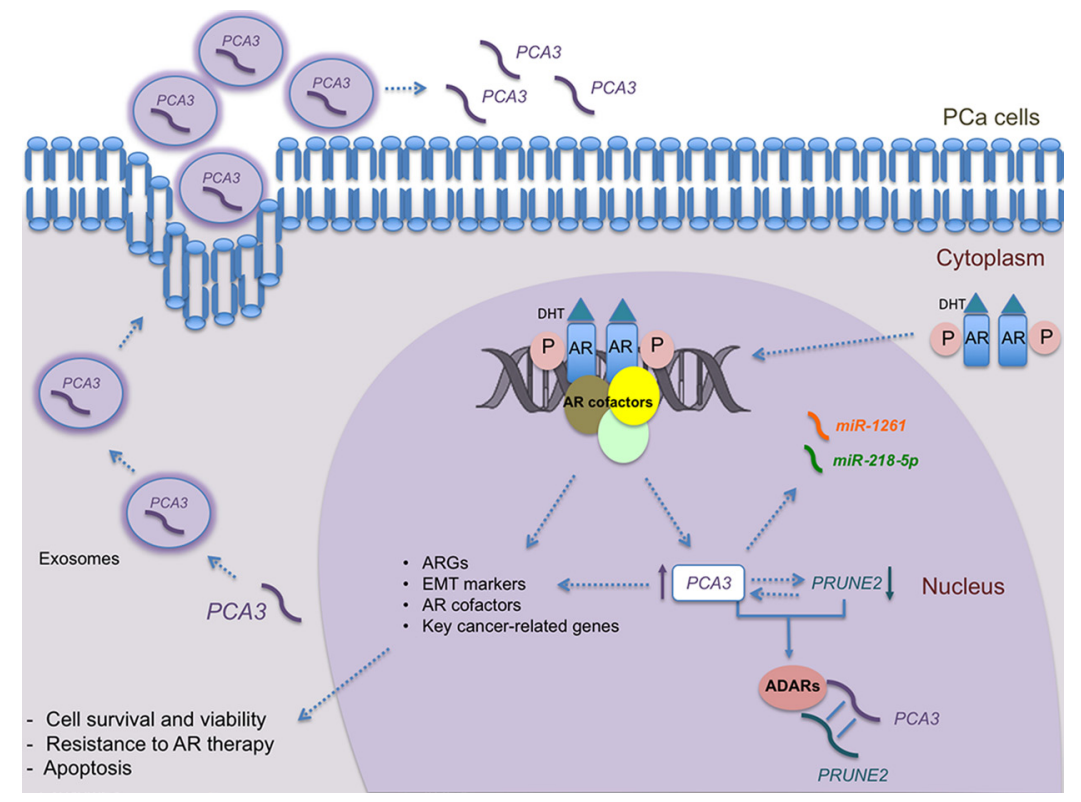

Figure 3: Overview of PCA3 roles in androgen responsive PCa cells. PCA3 transcript, which can be detected both into the nucleus and the cytoplasm, is regulated by androgen signaling. Androgen/DHT binds to the AR promoting its phosphorylation, which leads to its dimerization and translocation to the nucleus. Then, phosphorylated AR binds to the promoter region of target genes, activating their expression, including PCA3. PCA3 also modulates the expression of several key cancer-related genes, including ARGs, AR cofactors, EMT markers, and PRUNE2. The binding of PCA3 to PRUNE2 pre-mRNA forms a double-stranded complex, which is then linked to ADAR proteins, that in turn regulate PCA3 and PRUNE2 levels. Moreover, PCA3 negatively modulates PRUNE2 expression and vice-versa. Furthermore, PCA3 can modulate the availability of some miRNAs, such as miRNA-1261 and miR-218-5p, by base pairing with them. In addition to classical overexpression of PCA3 in body fluids and urine, PCA3 transcript has also been detected in exosomes, from which it can be delivered into the extracellular environment. DHT: dihydrotestoterone; PRUNE2: Prune Homolog 2 Coding; PCa: Prostate Cancer; PCA3: Prostate Cancer Antigen 3; miR: microRNAs; ADAR: Adenosine Deaminases that act on RNA; AR: Androgen Receptor; ARGs: Androgen-Responsive Genes; EMT: Epithelial-Mesenchymal Transition. 
healthy and cancer tissues, as well as in ovarian cancer cell lines, has been described [90]. PCA3 knockdown in ovarian cancer cells led to the suppression of cell migration, invasion and viability, besides induction of G1 cell cycle arrest and apoptotic cell death. The same report also proposed that the $P C A 3$ gene 3'UTR region presented a potential binding site to $m i R-106 \mathrm{~b}$ and that some genes regulated by this miRNA are also affected when $P C A 3$ expression is suppressed. Nevertheless, further data are needed to understand the mechanisms modulating PCA3 expression in ovarian cancer cells [91].

$P C A 3$ expression has also been described in a recent study aiming to characterize differentially expressed RNAs in Parkinson and Alzheimer diseases. PCA3 was found to be upregulated in cerebrospinal fluid exosomes extracted from both diseases, as compared to healthy controls [92]. These findings suggested that $P C A 3$ may also participate in the pathogenesis of such other diseases, and its use as a potential biomarker in these conditions should be further explored.

\section{FUTURE PERSPECTIVES AND DIRECTIONS}

In the last decade, an exciting boom of experimental research has brought to light the pivotal biological functions of lncRNAs, representing more than half of the non-coding transcriptome, along with their dysregulation in many diseases, including cancer [93]. In this context, PCA3 has been extensively studied since 1999, showing its involvement on modulating PCa survival, link to AR signaling, besides its relation to PRUNE2 expression and the potential ability to modulate the expression of key cancer-related genes. These known roles are summarized in Figure 3. However, there are still open questions to further understand its role in PCa biology, especially how its expression is controlled by AR signaling and its potential link to resistance to currently proposed therapies focused to these pathways. New studies should be devoted to investigate $P C A 3$ roles regarding potential utility in immunotherapy and its relation to immune system evasion during $\mathrm{PCa}$ development. Given the recent findings of $P C A 3$ in other tumor and pathologies, additional studies should better comprehend $P C A 3$ expression patterns and the factors that modulate $P C A 3$ aberrant expression in pathological conditions.

Altogether, these data showed that $P C A 3$ is able to modulate distinct signaling pathways, mostly those involved on cell survival [15]. Recent evidence also points $P C A 3$ as a regulator of transcriptional levels, mediated by ADARs [13], being able to target miRNAs [18] and possibly a precursor of several miRNAs, as has been shown for other lncRNAs [94]. The lncRNAs act as competing endogenous RNAs (ceRNAs), where RNA molecules regulate each other through their biding sites, triggering decay of the targeted lncRNAs [95]. We then speculate $P C A 3$ as a key regulator of gene expression by binding to several types of RNA molecules, especially those aberrantly expressed in pathological conditions. Once PCA3 has also been detected in other diseases beyond cancer, such as Alzheimer and Parkinson [92], and there is rising recognition that lncRNAs have been implicated in these processes [95], we then postulate that $P C A 3$, when aberrantly expressed in these diseases could post transcriptionally regulate the main regulatory pathways mediating these processes. All these possibilities open new avenues to target $P C A 3$ therapeutically to combat these pathological conditions.

\section{Author contributions}

AEGL, ARM, LBF and ERPG: Conceptualization; AEGL, ARM, LBF and ERPG: Writing - original draft; AEGL, ARM, LBF and ERPG: Writing - review \& editing; ARM and ERPG: Funding acquisition; ERPG: Project administration.

\section{ACKNOWLEDGMENTS AND FUNDING}

We are especially grateful to Carlos André Accacio Lemos for kind support on figures design and edition. We also thank Instituto Oswaldo Cruz from Fiocruz, CNPq, CAPES, FAPERJ, Proppi/UFF and Brazilian Ministry of Health for financial support.

\section{CONFLICTS OF INTEREST}

The authors declare no conflicts of interest.

\section{REFERENCES}

1. Bussemakers MJ, van Bokhoven A, Verhaegh GW, Smit FP, Karthaus HF, Schalken JA, Debruyne FM, Ru N, Isaacs WB. DD3: a new prostate-specific gene, highly overexpressed in prostate cancer. Cancer Res. 1999; 59: 5975-9. [PubMed]

2. Bhan A, Soleimani M, Mandal SS. Long Noncoding RNA and Cancer: A New Paradigm. Cancer Res. 2017; 77: 3965-81. https://doi.org/10.1158/0008-5472.CAN-16-2634. [PubMed]

3. Schalken JA, Hessels D, Verhaegh G. New targets for therapy in prostate cancer: differential display code 3 (DD3(PCA3)), a highly prostate cancer-specific gene. Urology. 2003; 62: 34-43. https://doi.org/10.1016/S00904295(03)00759-3. [PubMed]

4. Popa I, Fradet Y, Beaudry G, Hovington H, Beaudry G, Tetu B. Identification of PCA3 (DD3) in prostatic carcinoma by in situ hybridization. Mod Pathol. 2007; 20: 1121-7. https:// doi.org/10.1038/modpathol.3800963. [PubMed]

5. Marangoni K, Neves AF, Rocha RM, Faria PR, Alves PT, Souza AG, Fujimura PT, Santos FA, Araujo TG, Ward LS, 
Goulart LR. Prostate-specific RNA aptamer: promising nucleic acid antibody-like cancer detection. Sci Rep. 2015; 5: 12090. https://doi.org/10.1038/srep12090. [PubMed]

6. Clarke RA, Zhao Z, Guo AY, Roper K, Teng L, Fang ZM, Samaratunga H, Lavin MF, Gardiner RA. New genomic structure for prostate cancer specific gene PCA3 within BMCC1: implications for prostate cancer detection and progression. PLoS One. 2009; 4: e4995. https://doi. org/10.1371/journal.pone.0004995. [PubMed]

7. Salagierski M, Verhaegh GW, Jannink SA, Smit FP, Hessels D, Schalken JA. Differential expression of PCA3 and its overlapping PRUNE2 transcript in prostate cancer. Prostate. 2010; 70: 70-8. https://doi.org/10.1002/pros.21040. [PubMed]

8. Teixeira AA, Marchio S, Dias-Neto E, Nunes DN, da Silva IT, Chackerian B, Barry M, Lauer RC, Giordano RJ, Sidman RL, Wheeler CM, Cavenee WK, Pasqualini R, et al. Going viral? Linking the etiology of human prostate cancer to the PCA3 long noncoding RNA and oncogenic viruses. EMBO Mol Med. 2017; 9: 1327-30. https://doi. org/10.15252/emmm.201708072. [PubMed]

9. Kapusta A, Kronenberg Z, Lynch VJ, Zhuo X, Ramsay L, Bourque G, Yandell M, Feschotte C. Transposable elements are major contributors to the origin, diversification, and regulation of vertebrate long noncoding RNAs. PLoS Genet. 2013; 9: e1003470. https://doi.org/10.1371/journal. pgen.1003470. [PubMed]

10. He JH, Li BX, Han ZP, Zou MX, Wang L, Lv YB, Zhou JB, Cao MR, Li YG, Zhang JZ. Snail-activated long non-coding RNA PCA3 up-regulates PRKD3 expression by miR-1261 sponging, thereby promotes invasion and migration of prostate cancer cells. Tumour Biol. 2016 Oct 14. https:// doi.org/10.1007/s13277-016-5450-y. [Epub ahead of print]. [PubMed]

11. Cao S, Moss W, O'Grady T, Concha M, Strong MJ, Wang X, Yu Y, Baddoo M, Zhang K, Fewell C, Lin Z, Dong Y, Flemington EK. New Noncoding Lytic Transcripts Derived from the Epstein-Barr Virus Latency Origin of Replication, oriP, Are Hyperedited, Bind the Paraspeckle Protein, NONO/p54nrb, and Support Viral Lytic Transcription. J Virol. 2015; 89: 7120-32. https://doi.org/10.1128/ JVI.00608-15. [PubMed]

12. Ferreira LB, Palumbo A, de Mello KD, Sternberg C, Caetano MS, de Oliveira FL, Neves AF, Nasciutti LE, Goulart LR, Gimba ER. PCA3 noncoding RNA is involved in the control of prostate-cancer cell survival and modulates androgen receptor signaling. BMC Cancer. 2012; 12: 507. https://doi.org/10.1186/1471-2407-12-507. [PubMed]

13. Salameh A, Lee AK, Cardo-Vila M, Nunes DN, Efstathiou E, Staquicini FI, Dobroff AS, Marchio S, Navone NM, Hosoya H, Lauer RC, Wen S, Salmeron CC, et al. PRUNE2 is a human prostate cancer suppressor regulated by the intronic long noncoding RNA PCA3. Proc Natl Acad Sci U S A. 2015; 112: 8403-8. https://doi.org/10.1073/ pnas.1507882112. [PubMed]
14. Lemos AE, Ferreira LB, Batoreu NM, de Freitas PP, Bonamino MH, Gimba ER. PCA3 long noncoding RNA modulates the expression of key cancer-related genes in LNCaP prostate cancer cells. Tumour Biol. 2016; 37: 11339-48. https://doi.org/10.1007/s13277-016-5012-3. [PubMed]

15. Ozgur E, Celik AI, Darendeliler E, Gezer U. PCA3 Silencing Sensitizes Prostate Cancer Cells to Enzalutamidemediated Androgen Receptor Blockade. Anticancer Res. 2017; 37: 3631-7. https://doi.org/10.21873/ anticanres.11733. [PubMed]

16. Salmena L, Poliseno L, Tay Y, Kats L, Pandolfi PP. A ceRNA hypothesis: the Rosetta Stone of a hidden RNA language? Cell. 2011; 146: 353-8. https://doi.org/10.1016/j. cell.2011.07.014. [PubMed]

17. Kallen AN, Zhou XB, Xu J, Qiao C, Ma J, Yan L, Lu L, Liu C, Yi JS, Zhang H, Min W, Bennett AM, Gregory RI, et al. The imprinted H19 lncRNA antagonizes let-7 microRNAs. Mol Cell. 2013; 52: 101-12. https://doi.org/10.1016/j. molcel.2013.08.027. [PubMed]

18. Zhang G, He X, Ren C, Lin J, Wang Q. Long noncoding RNA PCA3 regulates prostate cancer through sponging miR-218-5p and modulating high mobility group box 1. J Cell Physiol. 2019; 234: 13097-13109. https://doi. org/10.1002/jcp.27980. [PubMed]

19. Li F, Gu C, Tian F, Jia Z, Meng Z, Ding Y, Yang J. MiR-218 impedes IL-6-induced prostate cancer cell proliferation and invasion via suppression of LGR4 expression. Oncol Rep. 2016; 35: 2859-65. https://doi.org/10.3892/or.2016.4663. [PubMed]

20. Nishikawa R, Goto Y, Sakamoto S, Chiyomaru T, Enokida H, Kojima S, Kinoshita T, Yamamoto N, Nakagawa M, Naya Y, Ichikawa T, Seki N. Tumor-suppressive microRNA-218 inhibits cancer cell migration and invasion via targeting of LASP1 in prostate cancer. Cancer Sci. 2014; 105: 802-11. https://doi.org/10.1111/cas.12441. [PubMed]

21. Guan B, Wu K, Zeng J, Xu S, Mu L, Gao Y, Wang K, Ma Z, Tian J, Shi Q, Guo P, Wang X, He D, et al. Tumorsuppressive microRNA-218 inhibits tumor angiogenesis via targeting the mTOR component RICTOR in prostate cancer. Oncotarget. 2017; 8: 8162-72. https://doi.org/10.18632/ oncotarget.14131. [PubMed]

22. Shi D, Zhang Y, Lu R, Zhang Y. The long non-coding RNA MALAT1 interacted with miR-218 modulates choriocarcinoma growth by targeting Fbxw8. Biomed Pharmacother. 2018; 97: 543-50. https://doi.org/10.1016/j. biopha.2017.10.083. [PubMed]

23. Zhang H, Zhong J, Bian Z, Fang X, Peng Y, Hu Y. Long non-coding RNA CCAT1 promotes human retinoblastoma SO-RB50 and Y79 cells through negative regulation of miR-218-5p. Biomed Pharmacother. 2017; 87: 683-91. https://doi.org/10.1016/j.biopha.2017.01.004. [PubMed]

24. Neves AF, Araujo TG, Biase WK, Meola J, Alcantara TM, Freitas DG, Goulart LR. Combined analysis of multiple 
mRNA markers by RT-PCR assay for prostate cancer diagnosis. Clin Biochem. 2008; 41: 1191-8. https://doi. org/10.1016/j.clinbiochem.2008.06.013. [PubMed]

25. Klecka J, Holubec L, Pesta M, Topolcan O, Hora M, Eret V, Finek J, Chottova-Dvorakova M, Babjuk M, Novak K, Stolz J. Differential display code 3 (DD3/PCA3) in prostate cancer diagnosis. Anticancer Res. 2010; 30: 665-70. [PubMed]

26. Pal RP, Maitra NU, Mellon JK, Khan MA. Defining prostate cancer risk before prostate biopsy. Urol Oncol. 2013; 31: 1408-18. https://doi.org/10.1016/j.urolonc.2012.05.012. [PubMed]

27. Pejcic T, Hadzi-Djokic J, Topuzovic C, Basic D, Marjanovic A, Djurasic L. The analysis of some factors that influence on serum PSA level in localized prostate cancer patients: mathematical model. Acta Chir Iugosl. 2011; 58: 81-7. https://doi.org/10.2298/ACI1101081P. [PubMed]

28. Truong M, Yang B, Jarrard DF. Toward the detection of prostate cancer in urine: a critical analysis. J Urol. 2013; 189: 422-9. https://doi.org/10.1016/j.juro.2012.04.143. [PubMed]

29. Salagierski M, Schalken JA. Molecular diagnosis of prostate cancer: PCA3 and TMPRSS2:ERG gene fusion. J Urol. 2012; 187: 795-801. https://doi.org/10.1016/j. juro.2011.10.133. [PubMed]

30. Groskopf J, Aubin SM, Deras IL, Blase A, Bodrug S, Clark C, Brentano S, Mathis J, Pham J, Meyer T, Cass M, Hodge P, Macairan ML, et al. APTIMA PCA3 molecular urine test: development of a method to aid in the diagnosis of prostate cancer. Clin Chem. 2006; 52: 1089-95. https://doi. org/10.1373/clinchem.2005.063289. [PubMed]

31. Roobol MJ, Schroder FH, van Leeuwen P, Wolters T, van den Bergh RC, van Leenders GJ, Hessels D. Performance of the prostate cancer antigen 3 (PCA3) gene and prostate-specific antigen in prescreened men: exploring the value of PCA3 for a first-line diagnostic test. Eur Urol. 2010; 58: 475-81. https://doi.org/10.1016/j.eururo.2010.06.039. [PubMed]

32. Thompson IM, Pauler DK, Goodman PJ, Tangen CM, Lucia MS, Parnes HL, Minasian LM, Ford LG, Lippman SM, Crawford ED, Crowley JJ, Coltman CA Jr. Prevalence of prostate cancer among men with a prostate-specific antigen level $<$ or $=4.0 \mathrm{ng}$ per milliliter. N Engl J Med. 2004; 350: 2239-46. https://doi.org/10.1056/NEJMoa031918. [PubMed]

33. Ploussard G, Haese A, Van Poppel H, Marberger M, Stenzl A, Mulders PF, Huland H, Bastien L, Abbou CC, Remzi M, Tinzl M, Feyerabend S, Stillebroer AB, et al. The prostate cancer gene 3 (PCA3) urine test in men with previous negative biopsies: does free-to-total prostate-specific antigen ratio influence the performance of the PCA3 score in predicting positive biopsies? BJU Int. 2010; 106: 1143-7. https://doi.org/10.1111/j.1464-410X.2010.09286.x. [PubMed]

34. Marks LS, Fradet Y, Deras IL, Blase A, Mathis J, Aubin SM, Cancio AT, Desaulniers M, Ellis WJ, Rittenhouse H,
Groskopf J. PCA3 molecular urine assay for prostate cancer in men undergoing repeat biopsy. Urology. 2007; 69: 5325. https://doi.org/10.1016/j.urology.2006.12.014. [PubMed]

35. Fenner A. Prostate cancer: PCA3 as a Grade Reclassification Predictor. Nat Rev Urol. 2017; 14: 390. https://doi.org/10.1038/nrurol.2017.70. [PubMed]

36. Aubin SM, Reid J, Sarno MJ, Blase A, Aussie J, Rittenhouse H, Rittmaster R, Andriole GL, Groskopf J. PCA3 molecular urine test for predicting repeat prostate biopsy outcome in populations at risk: validation in the placebo arm of the dutasteride REDUCE trial. J Urol. 2010; 184: 1947-52. https://doi.org/10.1016/i.juro.2010.06.098. [PubMed]

37. van Poppel H, Haese A, Graefen M, de la Taille A, Irani J, de Reijke T, Remzi M, Marberger M. The relationship between Prostate CAncer gene 3 (PCA3) and prostate cancer significance. BJU Int. 2012; 109: 360-6. https://doi. org/10.1111/j.1464-410X.2011.10377.x. [PubMed]

38. Haese A, de la Taille A, van Poppel H, Marberger M, Stenzl A, Mulders PF, Huland H, Abbou CC, Remzi M, Tinzl M, Feyerabend S, Stillebroer AB, van Gils MP, et al. Clinical utility of the PCA3 urine assay in European men scheduled for repeat biopsy. Eur Urol. 2008; 54: 1081-8. https://doi. org/10.1016/j.eururo.2008.06.071. [PubMed]

39. Whitman EJ, Groskopf J, Ali A, Chen Y, Blase A, Furusato B, Petrovics G, Ibrahim M, Elsamanoudi S, Cullen J, Sesterhenn IA, Brassell S, Rittenhouse H, et al. PCA3 score before radical prostatectomy predicts extracapsular extension and tumor volume. J Urol. 2008; 180: 1975-8; discussion 1978-9. https://doi.org/10.1016/j. juro.2008.07.060. [PubMed]

40. Auprich M, Chun FK, Ward JF, Pummer K, Babaian R, Augustin H, Luger F, Gutschi S, Budaus L, Fisch M, Huland H, Graefen M, Haese A. Critical assessment of preoperative urinary prostate cancer antigen 3 on the accuracy of prostate cancer staging. Eur Urol. 2011; 59: 96-105. https://doi. org/10.1016/j.eururo.2010.10.024. [PubMed]

41. Deras IL, Aubin SM, Blase A, Day JR, Koo S, Partin AW, Ellis WJ, Marks LS, Fradet Y, Rittenhouse H, Groskopf J. PCA3: a molecular urine assay for predicting prostate biopsy outcome. J Urol. 2008; 179: 1587-92. https://doi. org/10.1016/j.juro.2007.11.038. [PubMed]

42. Ploussard G, Durand X, Xylinas E, Moutereau S, Radulescu C, Forgue A, Nicolaiew N, Terry S, Allory Y, Loric S, Salomon L, Vacherot F, de la Taille A. Prostate cancer antigen 3 score accurately predicts tumour volume and might help in selecting prostate cancer patients for active surveillance. Eur Urol. 2011; 59: 422-9. https://doi. org/10.1016/j.eururo.2010.11.044. [PubMed]

43. Wu AK, Reese AC, Cooperberg MR, Sadetsky N, Shinohara K. Utility of PCA3 in patients undergoing repeat biopsy for prostate cancer. Prostate Cancer Prostatic Dis. 2012; 15: 100-5. https://doi.org/10.1038/pcan.2011.52. [PubMed]

44. Nakanishi H, Groskopf J, Fritsche HA, Bhadkamkar V, Blase A, Kumar SV, Davis JW, Troncoso P, Rittenhouse H, Babaian RJ. PCA3 molecular urine assay correlates with 
prostate cancer tumor volume: implication in selecting candidates for active surveillance. J Urol. 2008; 179: 1804-9; discussion 1809-10. https://doi.org/10.1016/j. juro.2008.01.013. [PubMed]

45. Chun FK, de la Taille A, van Poppel H, Marberger M, Stenzl A, Mulders PF, Huland H, Abbou CC, Stillebroer AB, van Gils MP, Schalken JA, Fradet Y, Marks LS, et al. Prostate cancer gene 3 (PCA3): development and internal validation of a novel biopsy nomogram. Eur Urol. 2009; 56: 659-67. https://doi.org/10.1016/j.eururo.2009.03.029. [PubMed]

46. van Gils MP, Hessels D, Hulsbergen-van de Kaa CA, Witjes JA, Jansen CF, Mulders PF, Rittenhouse HG, Schalken JA. Detailed analysis of histopathological parameters in radical prostatectomy specimens and PCA3 urine test results. Prostate. 2008; 68: 1215-22. https://doi.org/10.1002/ pros.20781. [PubMed]

47. Tosoian JJ, Loeb S, Kettermann A, Landis P, Elliot DJ, Epstein JI, Partin AW, Carter HB, Sokoll LJ. Accuracy of PCA3 measurement in predicting short-term biopsy progression in an active surveillance program. J Urol. 2010; 183: 534-8. https://doi.org/10.1016/j.juro.2009.10.003. [PubMed]

48. Hessels D, van Gils MP, van Hooij O, Jannink SA, Witjes JA, Verhaegh GW, Schalken JA. Predictive value of PCA3 in urinary sediments in determining clinico-pathological characteristics of prostate cancer. Prostate. 2010; 70: 10-6. https://doi.org/10.1002/pros.21032. [PubMed]

49. Vlaeminck-Guillem V, Bandel M, Cottancin M, RodriguezLafrasse C, Bohbot JM, Sednaoui P. Chronic prostatitis does not influence urinary PCA3 score. Prostate. 2012; 72: 549-54. https://doi.org/10.1002/pros.21457. [PubMed]

50. De Luca S, Passera R, Milillo A, Coda R, Randone DF. Histological chronic prostatitis and high-grade prostate intra-epithelial neoplasia do not influence urinary prostate cancer gene 3 score. BJU Int. 2012; 110: E778-82. https:// doi.org/10.1111/j.1464-410X.2012.11645.x. [PubMed]

51. Durand X, Xylinas E, Radulescu C, Haus-Cheymol R, Moutereau S, Ploussard G, Forgues A, Robert G, Vacherot F, Loric S, Allory Y, Ruffion A, de la Taille A. The value of urinary prostate cancer gene 3 (PCA3) scores in predicting pathological features at radical prostatectomy. BJU Int. 2012; 110: 43-9. https://doi.org/10.1111/j.1464410X.2011.10682.x. [PubMed]

52. Siegrist TC, Panagopoulos G, Armenakas NA, Fracchia JA. PCA3 permutation increases the prostate biopsy yield. Community Oncol. 2012; 9: 243-6.

53. Ruffion A, Perrin P, Devonec M, Champetier D, Decaussin M, Paparel P, Vlaeminck-Guillem V. Additional value of PCA3 density to predict initial prostate biopsy outcome. World J Urol. 2014; 32: 917-23. https://doi.org/10.1007/ s00345-014-1251-3. [PubMed]

54. Ruffion A, Devonec M, Champetier D, Decaussin-Petrucci M, Rodriguez-Lafrasse C, Paparel P, Perrin P, VlaeminckGuillem V. PCA3 and PCA3-based nomograms improve diagnostic accuracy in patients undergoing first prostate biopsy. Int J Mol Sci. 2013; 14: 17767-80. https://doi. org/10.3390/ijms 140917767. [PubMed]

55. Zheng K, Dou Y, He L, Li H, Zhang Z, Chen Y, Ye A, Liu W, Kong L. Improved sensitivity and specificity for prostate cancer diagnosis based on the urine PCA3/PSA ratio acquired by sequencespecific RNA capture. Oncol Rep. 2015; 34: 2439-44. https://doi.org/10.3892/or.2015.4266. [PubMed]

56. Sioss JA, Bhiladvala RB, Pan W, Li M, Patrick S, Xin $\mathrm{P}$, Dean SL, Keating CD, Mayer TS, Clawson GA. Nanoresonator chip-based RNA sensor strategy for detection of circulating tumor cells: response using PCA3 as a prostate cancer marker. Nanomedicine. 2012; 8: 1017-25. https://doi.org/10.1016/j.nano.2011.11.009. [PubMed]

57. Yang Z, Yu L, Wang Z. PCA3 and TMPRSS2-ERG gene fusions as diagnostic biomarkers for prostate cancer. Chin J Cancer Res. 2016; 28: 65-71. https://doi.org/10.3978/j. issn.1000-9604.2016.01.05. [PubMed]

58. Mikhaylenko DS, Perepechin DV, Grigoryeva MV, Zhinzhilo TA, Safronova NY, Efremov GD, Sivkov AV. [PCA3 AND TMPRSS2:ERG GENES EXPRESSION IN BIOPSIES OF BENIGN PROSTATE HYPERPLASIA, INTRAEPITHELIAL NEOPLASIA, AND PROSTATE CANCER]. [Article in Russian]. Urologiia. 2015; 46-50. [PubMed]

59. Merdan S, Tomlins SA, Barnett CL, Morgan TM, Montie JE, Wei JT, Denton BT. Assessment of long-term outcomes associated with urinary prostate cancer antigen 3 and TMPRSS2:ERG gene fusion at repeat biopsy. Cancer. 2015; 121: 4071-9. https://doi.org/10.1002/cncr.29611. [PubMed]

60. Stephan C, Jung K, Semjonow A, Schulze-Forster K, Cammann H, Hu X, Meyer HA, Bogemann M, Miller K, Friedersdorff F. Comparative assessment of urinary prostate cancer antigen 3 and TMPRSS2:ERG gene fusion with the serum [-2]proprostate-specific antigen-based prostate health index for detection of prostate cancer. Clin Chem. 2013; 59: 280-8. https://doi.org/10.1373/clinchem.2012.195560. [PubMed]

61. Robert G, Jannink S, Smit F, Aalders T, Hessels D, Cremers R, Mulders PF, Schalken JA. Rational basis for the combination of PCA3 and TMPRSS2:ERG gene fusion for prostate cancer diagnosis. Prostate. 2013; 73: 113-20. https://doi.org/10.1002/pros.22546. [PubMed]

62. Clark J, Merson S, Jhavar S, Flohr P, Edwards S, Foster CS, Eeles R, Martin FL, Phillips DH, Crundwell M, Christmas T, Thompson A, Fisher C, et al. Diversity of TMPRSS2ERG fusion transcripts in the human prostate. Oncogene. 2007; 26: 2667-73. https://doi.org/10.1038/sj.onc.1210070. [PubMed]

63. Sanda MG, Feng Z, Howard DH, Tomlins SA, Sokoll LJ, Chan DW, Regan MM, Groskopf J, Chipman J, Patil DH, Salami SS, Scherr DS, Kagan J, et al. Association Between Combined TMPRSS2:ERG and PCA3 RNA Urinary 
Testing and Detection of Aggressive Prostate Cancer. JAMA Oncol. 2017; 3: 1085-93. https://doi.org/10.1001/ jamaoncol.2017.0177. [PubMed]

64. Mao Z, Ji A, Yang K, He W, Hu Y, Zhang Q, Zhang D, Xie L. Diagnostic performance of PCA3 and hK2 in combination with serum PSA for prostate cancer. Medicine (Baltimore). 2018; 97: e12806. https://doi.org/10.1097/ MD.0000000000012806. [PubMed]

65. Cao L, Lee CH, Ning J, Handy BC, Wagar EA, Meng QH. Combination of Prostate Cancer Antigen 3 and ProstateSpecific Antigen Improves Diagnostic Accuracy in Men at Risk of Prostate Cancer. Arch Pathol Lab Med. 2018; 142: 1106-12. https://doi.org/10.5858/arpa.2017-0185-OA. [PubMed]

66. Rigau M, Ortega I, Mir MC, Ballesteros C, Garcia M, Llaurado M, Colas E, Pedrola N, Montes M, Sequeiros T, Ertekin T, Majem B, Planas J, et al. A three-gene panel on urine increases PSA specificity in the detection of prostate cancer. Prostate. 2011; 71: 1736-45. https://doi. org/10.1002/pros.21390. [PubMed]

67. Xu LL, Stackhouse BG, Florence K, Zhang W, Shanmugam N, Sesterhenn IA, Zou Z, Srikantan V, Augustus M, Roschke V, Carter K, McLeod DG, Moul JW, et al. PSGR, a novel prostate-specific gene with homology to a $\mathrm{G}$ proteincoupled receptor, is overexpressed in prostate cancer. Cancer Res. 2000; 60: 6568-72. [PubMed]

68. Mearini E, Antognelli C, Del Buono C, Cochetti G, Giannantoni A, Nardelli E, Talesa VN. The combination of urine DD3(PCA3) mRNA and PSA mRNA as molecular markers of prostate cancer. Biomarkers. 2009; 14: 235-43. https://doi.org/10.1080/13547500902807306. [PubMed]

69. Loeb S, Vellekoop A, Ahmed HU, Catto J, Emberton M, Nam R, Rosario DJ, Scattoni V, Lotan Y. Systematic review of complications of prostate biopsy. Eur Urol. 2013; 64: 876-92. https://doi.org/10.1016/j.eururo.2013.05.049. [PubMed]

70. Ferro M, Lucarelli G, Bruzzese D, Perdona S, Mazzarella C, Perruolo G, Marino A, Cosimato V, Giorgio E, Tagliamonte V, Bottero D, De Cobelli O, Terracciano D. Improving the prediction of pathologic outcomes in patients undergoing radical prostatectomy: the value of prostate cancer antigen 3 (PCA3), prostate health index (phi) and sarcosine. Anticancer Res. 2015; 35: 1017-23. [PubMed]

71. Cantiello F, Russo GI, Cicione A, Ferro M, Cimino S, Favilla V, Perdona S, De Cobelli O, Magno C, Morgia G, Damiano R. PHI and PCA3 improve the prognostic performance of PRIAS and Epstein criteria in predicting insignificant prostate cancer in men eligible for active surveillance. World J Urol. 2016; 34: 485-93. https://doi. org/10.1007/s00345-015-1643-z. [PubMed]

72. Leyten GH, Hessels D, Jannink SA, Smit FP, de Jong H, Cornel EB, de Reijke TM, Vergunst H, Kil P, Knipscheer BC, van Oort IM, Mulders PF, Hulsbergen-van de Kaa $\mathrm{CA}$, et al. Prospective multicentre evaluation of PCA3 and
TMPRSS2-ERG gene fusions as diagnostic and prognostic urinary biomarkers for prostate cancer. Eur Urol. 2014; 65: 534-42. https://doi.org/10.1016/j.eururo.2012.11.014. [PubMed]

73. Tallon L, Luangphakdy D, Ruffion A, Colombel M, Devonec M, Champetier D, Paparel P, Decaussin-Petrucci M, Perrin P, Vlaeminck-Guillem V. Comparative evaluation of urinary PCA3 and TMPRSS2: ERG scores and serum PHI in predicting prostate cancer aggressiveness. Int J Mol Sci. 2014; 15: 13299-316. https://doi.org/10.3390/ ijms150813299. [PubMed]

74. Wei W, Leng J, Shao H, Wang W. High PCA3 scores in urine correlate with poor-prognosis factors in prostate cancer patients. Int J Clin Exp Med. 2015; 8: 16606-12. [PubMed]

75. Merola R, Tomao L, Antenucci A, Sperduti I, Sentinelli S, Masi S, Mandoj C, Orlandi G, Papalia R, Guaglianone S, Costantini M, Cusumano G, Cigliana G, et al. PCA3 in prostate cancer and tumor aggressiveness detection on 407 high-risk patients: a National Cancer Institute experience. J Exp Clin Cancer Res. 2015; 34: 15. https://doi.org/10.1186/ s13046-015-0127-8. [PubMed]

76. Tosoian JJ, Patel HD, Mamawala M, Landis P, Wolf S, Elliott DJ, Epstein JI, Carter HB, Ross AE, Sokoll LJ, Pavlovich CP. Longitudinal assessment of urinary PCA3 for predicting prostate cancer grade reclassification in favorable-risk men during active surveillance. Prostate Cancer Prostatic Dis. 2017; 20: 339-42. https://doi. org/10.1038/pcan.2017.16. [PubMed]

77. Fradet V, Toren P, Nguile-Makao M, Lodde M, Levesque J, Leger C, Caron A, Bergeron A, Ben-Zvi T, Lacombe L, Pouliot F, Tiguert R, Dujardin T, et al. Prognostic value of urinary prostate cancer antigen 3 (PCA3) during active surveillance of patients with low-risk prostate cancer receiving 5alpha-reductase inhibitors. BJU Int. 2018; 121: 399-404. https://doi.org/10.1111/bju.14041. [PubMed]

78. Rodon N, Trias I, Verdu M, Calvo M, Banus JM, Puig X. Correlation of mRNA-PCA3 urine levels with the new grading system in prostate cancer. Rev Esp Patol. 2019; 52: 20-6. https://doi.org/10.1016/j.patol.2018.04.003. [PubMed]

79. Alshalalfa M, Verhaegh GW, Gibb EA, Santiago-Jimenez M, Erho N, Jordan J, Yousefi K, Lam LLC, Kolisnik T, Chelissery J, Seiler R, Ross AE, Karnes RJ, et al. Low PCA3 expression is a marker of poor differentiation in localized prostate tumors: exploratory analysis from 12,076 patients. Oncotarget. 2017; 8: 50804-13. https:// doi.org/10.18632/oncotarget.15133. [PubMed]

80. Porpiglia F, Cantiello F, De Luca S, Manfredi M, Veltri A, Russo F, Sottile A, Damiano R. In-parallel comparative evaluation between multiparametric magnetic resonance imaging, prostate cancer antigen 3 and the prostate health index in predicting pathologically confirmed significant prostate cancer in men eligible for active surveillance. BJU 
Int. 2016; 118: 527-34. https://doi.org/10.1111/bju.13318. [PubMed]

81. Leyten GH, Wierenga EA, Sedelaar JP, van Oort IM, Futterer JJ, Barentsz JO, Schalken JA, Mulders PF. Value of PCA3 to predict biopsy outcome and its potential role in selecting patients for multiparametric MRI. Int $\mathrm{J}$ Mol Sci. 2013; 14: 11347-55. https://doi.org/10.3390/ ijms140611347. [PubMed]

82. Vlaeminck-Guillem V, Devonec $\mathrm{M}$, Colombel $\mathrm{M}$, Rodriguez-Lafrasse C, Decaussin-Petrucci M, Ruffion A. Urinary PCA3 score predicts prostate cancer multifocality. J Urol. 2011; 185: 1234-9. https://doi.org/10.1016/j. juro.2010.11.072. [PubMed]

83. Martinez-Pineiro L, Schalken JA, Cabri P, Maisonobe $\mathrm{P}$, de la Taille A, Triptocare Study Group. Evaluation of urinary prostate cancer antigen-3 (PCA3) and TMPRSS2ERG score changes when starting androgen-deprivation therapy with triptorelin 6-month formulation in patients with locally advanced and metastatic prostate cancer. BJU Int. 2014; 114: 608-16. https://doi.org/10.1111/bju.12542. [PubMed]

84. van Gils MP, Hessels D, Peelen WP, Vergunst H, Mulders PF, Schalken JA. Preliminary evaluation of the effect of dutasteride on PCA3 in post-DRE urine sediments: a randomized, open-label, parallel-group pilot study. Prostate. 2009; 69: 1624-34. https://doi.org/10.1002/pros.21011. [PubMed]

85. Mitchell PJ, Welton J, Staffurth J, Court J, Mason MD, Tabi Z, Clayton A. Can urinary exosomes act as treatment response markers in prostate cancer? J Transl Med. 2009; 7: 4. https://doi.org/10.1186/1479-5876-7-4. [PubMed]

86. Tanase CP, Codrici E, Popescu ID, Mihai S, Enciu AM, Necula LG, Preda A, Ismail G, Albulescu R. Prostate cancer proteomics: Current trends and future perspectives for biomarker discovery. Oncotarget. 2017; 8: 18497-512. https://doi.org/10.18632/oncotarget.14501. [PubMed]
87. Miranda KC, Bond DT, McKee M, Skog J, Paunescu TG, Da Silva N, Brown D, Russo LM. Nucleic acids within urinary exosomes/microvesicles are potential biomarkers for renal disease. Kidney Int. 2010; 78: 191-9. https://doi. org/10.1038/ki.2010.106. [PubMed]

88. Motamedinia P, Scott AN, Bate KL, Sadeghi N, Salazar G, Shapiro E, Ahn J, Lipsky M, Lin J, Hruby GW, Badani KK, Petrylak DP, Benson MC, et al. Urine Exosomes for NonInvasive Assessment of Gene Expression and Mutations of Prostate Cancer. PLoS One. 2016; 11: e0154507. https://doi. org/10.1371/journal.pone.0154507. [PubMed]

89. Schalken JA. Validation of molecular targets in prostate cancer. BJU Int. 2005; 96: 23-9. https://doi.org/10.1111/ j.1464-410X.2005.05943.X. [PubMed]

90. Liu Y, Zong ZH, Guan X, Wang LL, Zhao Y. The role of long non-coding RNA PCA3 in epithelial ovarian carcinoma tumorigenesis and progression. Gene. 2017; 633: 42-7. https://doi.org/10.1016/j.gene.2017.08.027. [PubMed]

91. Schmitt AM, Chang HY. Gene regulation: Long RNAs wire up cancer growth. Nature. 2013; 500: 536-7. https://doi. org/10.1038/nature12548. [PubMed]

92. Gui Y, Liu H, Zhang L, Lv W, Hu X. Altered microRNA profiles in cerebrospinal fluid exosome in Parkinson disease and Alzheimer disease. Oncotarget. 2015; 6: 37043-53. https://doi.org/10.18632/oncotarget.6158. [PubMed]

93. Fang Y, Fullwood MJ. Roles, Functions, and Mechanisms of Long Non-coding RNAs in Cancer. Genomics Proteomics Bioinformatics. 2016; 14: 42-54. https://doi.org/10.1016/j. gpb.2015.09.006. [PubMed]

94. Yamamura S, Imai-Sumida M, Tanaka Y, Dahiya R. Interaction and cross-talk between non-coding RNAs. Cell Mol Life Sci. 2018; 75: 467-84. https://doi.org/10.1007/ s00018-017-2626-6. [PubMed]

95. Idda ML, Munk R, Abdelmohsen K, Gorospe M. Noncoding RNAs in Alzheimer's disease. Wiley Interdiscip Rev RNA. 2018; 9. https://doi.org/10.1002/wrna.1463. [PubMed] 